\title{
Peripheral gaint cell granuloma in a 9 year old girl
}

\author{
Chanchala H.P ${ }^{1 *}$, M.L Avinash Tejasvi ${ }^{2}$ \\ ${ }^{1}$ Lecturer, ${ }^{2}$ Professor, ${ }^{1}$ Dept. of Pedodontics and Preventive Dentistry, ${ }^{2}$ Dept. of Oral Medicine and Radiology, ${ }^{1}$ JSS Dental College and \\ Hospital, A Constituent College of JSS University, Mysore, Karnataka, ${ }^{2}$ Kamineni Institute of Dental Sciences, Narketpally, Telangana, \\ India
}

\section{*Corresponding Author: Chanchala HP}

Email: chanchala.manish@gmail.com

\begin{abstract}
The peripheral giant cell granuloma (PGCG) is a relatively common benign reactive lesion of the oral cavity, originating from the periosteum or the periodontal ligament. It occurs as a result of local trauma or chronic irritation. This article presents a case of peripheral giant cell granuloma with review of literature.

A 9 year old girl reported with a nodular lesion in the maxillary right central incisor region of two months duration. The lesion was excised and sent for histopathologic examination. The lesion was diagnosed as PGCG. The usual line of treatment for PGCG is local excision down to the bony base along with elimination of the local etiologic factors. The clinical one year follow up revealed there was no uneventful soft tissue healing or recurrence.
\end{abstract}

Keywords: Peripheral giant cell granuloma, Epulis, Giant cells, First decade, Female.

\section{Introduction}

The peripheral giant cell granuloma (PGCG) is a relatively common tumour-like growth of the oral cavity. It is also known as giant cell epulis or peripheral giant cell reparative granuloma. ${ }^{1}$ It accounts for $7 \%$ of all benign tumors of the jaw. ${ }^{2}$ Although PGCG is the least commonly diagnosed among the various hyperplastic gingival lesions (pyogenic granuloma, fibrous hyperplasia, peripheral ossifying fibroma) $)^{3,4}$ it is a common giant cell lesion found in the oral cavity. ${ }^{3}$ It is probably a reactive lesion caused by local irritation or traumal which resulted in gingival or mucosal hemorrhage. ${ }^{5}$ The aggressive factors include trauma, tooth extraction, badly finished restorations, plaque, calculus, chronic infections and impacted food. ${ }^{5-7}$ The origin of the multinucleated giant cells is unknown; some believe them to show immunohistochemical features of osteoclasts, while others suggest them to arise from mononuclear phagocyte system. ${ }^{1}$ Other possible sources include osteoblasts, endothelial cells and spindle cells. ${ }^{7}$ PGCG seems to be influenced by hormonal stimulus, especially estrogen..$^{6,8,9}$ PGCG occurs exclusively on gingiva or edentulous alveolar ridge 1 as variable sized, sessile or pedunculated lesion which is usually deep red to bluish red and bleed easily. ${ }^{10}$ The final diagnosis however relies on the histological diagnosis. ${ }^{8,11}$ Histologically, fibroblasts are the basic elements. Scattered among the fibroblasts are abundant multinucleated giant cells. Islands of metaplastic bone occasionally may be seen. ${ }^{12}$ Numerous capillaries may be seen along with areas of hemorrhage, hemosiderin and inflammatory cells throughout the cellular connective tissue. ${ }^{3,5,9,13,14}$ The treatment is usually local surgical excision down to underlying bone along with scaling of adjacent teeth to remove any source of irritation and to minimize risk of recurrence.

A recurrence rate of $10 \%$ has been reported. Usually PGCG occur at $4^{\text {th }}$ to $6^{\text {th }}$ decade of life and more common in men. Hence, we are reporting a case of PGCG in a 9 year old girl showing nodular growth in the upper front tooth region since 2 months.

\section{Case Report}

A 9 year old girl was referred by her physician to JSS Dental College\& Hospital, Mysore, Karnataka to assess a nodular growth on the gingiva of the maxillary anteriors in relation to the 21(maxillary left upper central incisor) present since 2 months. Thelesion was asymptomatic but for bleeding tendency on mastication. The medical history was non contributory and the patient was noton any medications. Intraoral examination revealed an exophytic, nodular growth, bluish-pink in color, firm in consistency which measured $0.75 \mathrm{~cm}$ in diameter. There was single tooth cross bite was noticed in relation to the same tooth region. (Fig. 1). No other oral findings where contributary apart from poor oral hygiene.

Periapical radiograph did not reveal superficial erosion of the alveolar crest in relation to the growth. Based on clinical and radiographic findings, the preliminary diagnosis for the lesion was fibroma. The differential diagnosis included pyogenic granuloma and peripheral giant cell granuloma. The lesion was excised under local anesthesia (Fig. 2) and the area was curetted. There were no complications in the immediate post-operative period. A full mouth scaling and root planing was carried out for the patient and oral hygiene instructions were given. No relapse has been observed during the 1 year follow-up. The excised specimen was sent for histopathologic examination.

The sections revealed well circumscribed, encapsulated cellular mass containing oval to spindle-shaped fibroblasts, abundant multinucleated giant cells, numerous capillaries and areas of hemorrhage. The multinucleated giant cells were of variable shapes and sizes containing open-faced nuclei ranging from 5 to 15 in number confirming to the type I giant cells described in literature. Few giant cells 
were found in association with and within blood vessels (Fig. 3, Fig. 4).

The presence of woven bony trabeculae deep to the tissue section were observed Fig. 5). The overlying epithelium was orthokeratinized stratified squamous epithelium which was mildly hyperplastic the histopathologic picture was diagnostic of peripheral giant cell granuloma.

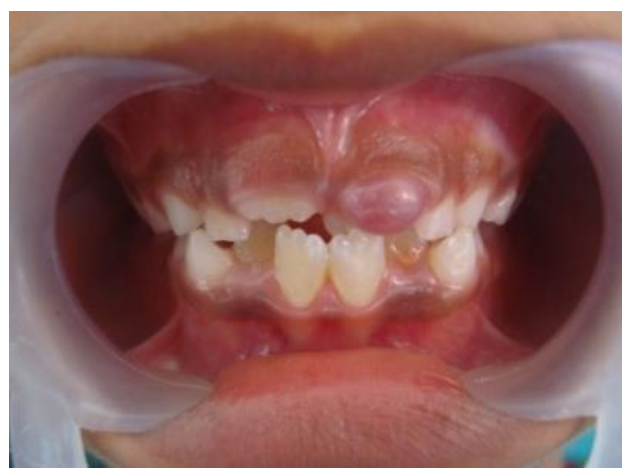

Fig. 1: Clinical picture of the lesion shows a bluishpinknodular growth on the labial gingiva in relation to the maxillary upper left central incisor, 21.

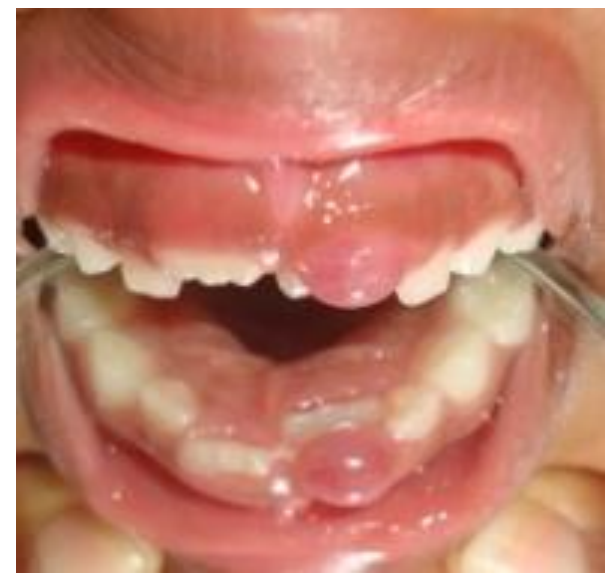

Fig. 2: Picture depicts the palatally displaced 21

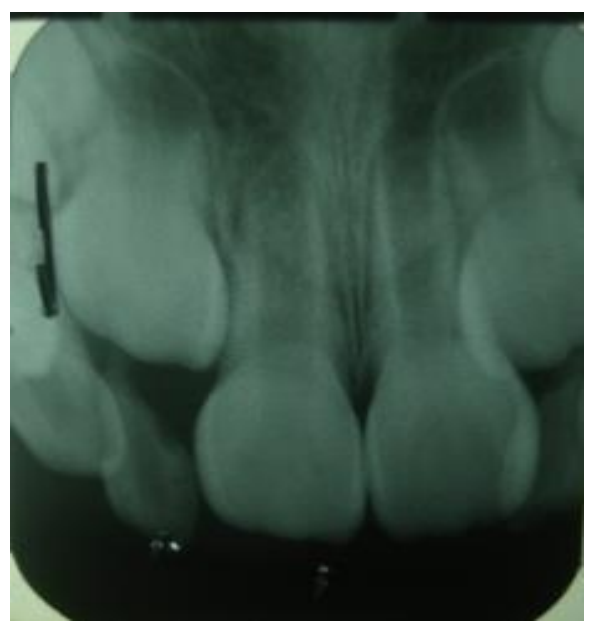

Fig. 3: No radiographic changes observed irt 21

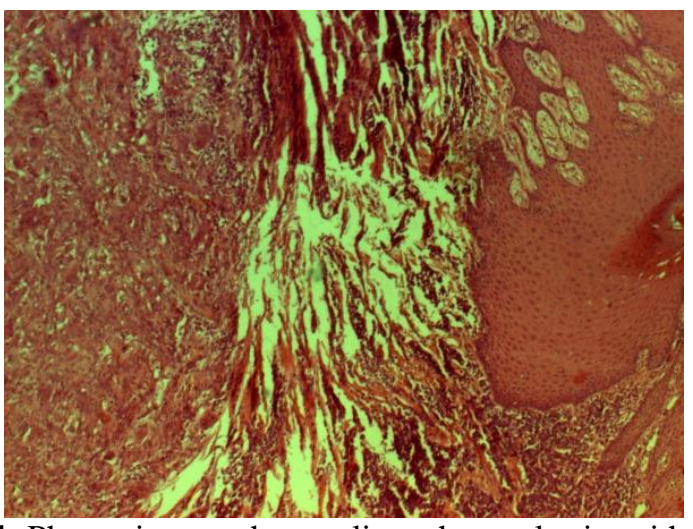

Fig. 4: Photomicrograph revealing a hyperplastic epithelium and connective tissue with multinucleated giant cells (H\&E, 10X).

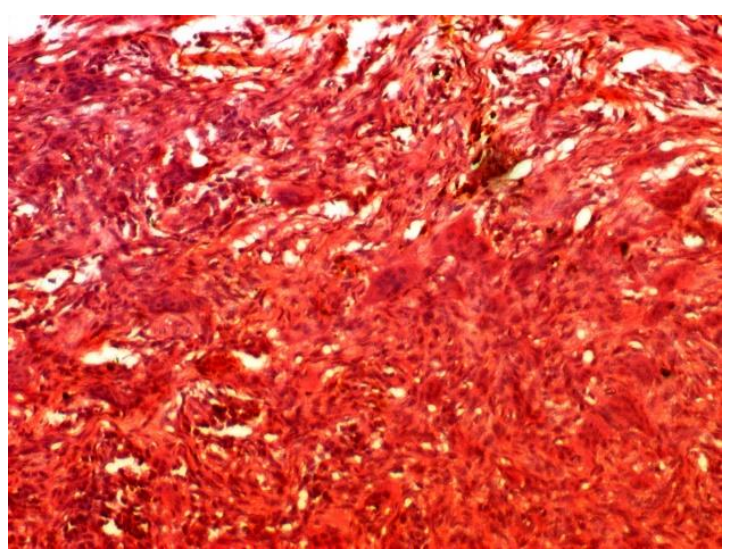

Fig. 5: Photomicrograph revealing multinucleated giant cells in a cellular vascular stroma under high power magnification (H\&, 45X)

\section{Discussion}

The present report is regarding a case of PGCG successfully treated with excision and curettage. The clinical and radiographic 1 year follow-up indicatedno recurrence and suggested that the chosen surgical management along with the maintenance of a scrupulous oral hygiene are adequate to treat PGCGand prevent its recurrence. Jaffe first suggested the term "giant cell reparativegranuloma" for the similar central lesion of the jaw bones ${ }^{3}$ to help differentiate them from the giant cell tumor ${ }^{15}$ as he believed the former lesion to represent a local reparative reaction rather than being a true neoplasm. ${ }^{16,17}$ Bernier and Cahn proposed the term "peripheral giant cell reparative granuloma" for thelesion. ${ }^{3}$ The latter terminology is currently not being used as the reparative nature of the lesion has not been proved. ${ }^{18}$ Today, the term peripheral giant cellgranuloma is universally accepted. ${ }^{3}$

The histogenesis of PGCG and the nature of the lesion remains controversial despite intense studies. A reactive nature of originhas been found in several immunohistochemical and ultrastructural studies. The mononuclear cells stain positive with histiocyte markers (lysozyme and alpha1-antichemotrypsin) as well as show a positive reaction with $\mathrm{CD}-68$, a macrophage-associated 
antigen. ${ }^{19,20}$ The presence of S-100 positive cells, which are evidence of Langerhans cells or their precursors, and the presence of fibroblasts, endothelial cells and myofibroblasts point toward a reactive nature of the PGCG. ${ }^{19,20,21}$

An origin from periosteum rather than gingiva has been suggested since the lesion can cause superficial erosion of bone and occurs in edentate as well as dentate areasof the jaws. ${ }^{22}$ At present, it is generally agreed that PGCG is a reactive, non-neoplastic lesion formed by granuloma-like tissue dominated by multinucleatedgiant cells. ${ }^{6}$ PGCG may occur at any age, especially during the firstto sixth decades of life. ${ }^{1}$ However, the highest incidence $(40 \%)$ is in the fourth to the sixth decades of life., ${ }^{3,9,23}$ A survey by Maryam AHP showed a relative predilection in the first four decades of life.2 A slight female predilection has been reported in a large number of studies ${ }^{14}$ with the male: female ratio. $1: 1 .^{5,24}$ A female predilection of $60 \%$ has been reported. ${ }^{1,3}$ The gender predilection was found to be more significant among patients with larger PGCG in a study carried out by Bodner et al. ${ }^{25}$ However, PGCG was more common among men $\left(\mathrm{M} / \mathrm{F}\right.$ 1.4:1) in a study by Zareiet al. ${ }^{26}$ Similar male predilections have been reported by Bhaskar SN et al. ${ }^{5}$ Salum FG et al., ${ }^{27}$ Chaparro-Avendano AV et $\mathrm{al}^{28}$ and Peralles PG et al. ${ }^{29}$

In ourpresent case, the patient is a 9 year old female, the size of the lesion is usually smaller than $2 \mathrm{~cm}$ in diameter, although larger ones may be seen occasionally; 1 $\mathrm{cm}$ to as large as $5 \mathrm{~cm}$ has been reported. ${ }^{25}$ Gradual growth in some cases, produces an important tumor mass that adversely affects normaloral function. ${ }^{28}$ The maximum capability of peripheral giant cell granuloma to expand is unknown. It is likely that expansion of the peripheral giant cell granulomais a relatively slow process and that most lesions are diagnosed and surgically removed before they reach their full growth potential. ${ }^{25}$ Peripheral giant cell granulomas larger than $2 \mathrm{~cm}$ are seen more commonly in females ${ }^{11,25}$ with poor oral hygiene and xerostomia.

This may indicate the important role of oral hygiene in the development and growth of peripheral giant cell granuloma. However, the association of large PGCG to oral or systemic factors is unclear. ${ }^{25}$ Lesion growth in most cases is induced by repeated trauma. ${ }^{7}$ The size of the lesion in the given case is within the above mentioned range.

PGCG varies in appearance from smooth, well demarcated ${ }^{25}$ regularly outlined mass to irregularly shaped, multilobulated protruberance with surface indentation. Ulceration of the margin is occasionally seen, ${ }^{18}$ secondary to trauma which may give the lesion a focal yellow zone as a result of the formation of a fibrin clot over the ulcer. ${ }^{12}$ The lesion often clinically resembles a pyogenic granuloma. ${ }^{30}$ The color can range from dark red to purple or blue. ${ }^{28}$ The lesion appears blue-purple in color due to extensive hemorrhagic areas and hemosiderin deposition at the periphery. ${ }^{1,3}$ PGCG is seen in the anterior or posterior region1 of the gingival or the soft tissue covering the edentulous alveolar ridge (18\%), ${ }^{5,13}$ Usually found in the gingival margin between teeth anterior to the permanent molars, 31 with the premolar molar region of the jaw being the most common site of occurrence. ${ }^{25} 5 \%$ cases were reported on the palate in a study by Maryam et al. ${ }^{2}$ There are no reported cases occurring in extragingival sites. ${ }^{3,7,14}$ This may be related to the anatomic nature of the gingival and the irritational factors at this site.7,14,32 The mandible is affected slightly more often than the maxilla, ${ }^{1,25}$ the reported proportion being 2.4:1. ${ }^{24}$ However, in our case the lesion was found in the maxillary arch. Upon palpation, one may note a lesion that is either soft or hard, depending on the composition of collagen and/or inflammatory components. ${ }^{24}$ In the given case, the lesion was an exophytic, sessile nodular growth which was bluish-pink in color, firm in consistency and was found on the palatal gingiva in relation to rightmaxillary anterior region involving the interdental papilla. Although the peripheral giant cell granuloma develops within soft tissue, "cupping" resorption of the underlyingalveolar bone is sometimes seen radiographically. ${ }^{1,12}$ This resorptive pattern is seen when the lesion occurs on edentulous ridge. ${ }^{12}$ In some cases radiographic findings may point toward the possible irritational factor. ${ }^{25}$ This is in contrast to the central giant cell granuloma, where radiography is an important diagnostic tool. ${ }^{33}$

$\mathrm{X}$-rays are important for determining whether the lesion is of gingival (i.e. peripheral) origin or of bone (central) origin with spread toward the surface. ${ }^{28}$ Radiographic evidence of superficial erosion of the crestal bone was evident in the given case. There are no pathognomonic clinical features whereby these lesions can be differentiated from other forms of gingival enlargement ${ }^{18}$ including pyogenic granuloma, fibrousepulis, peripheral ossifying fibroma, inflammatory fibrous hyperplasia, peripheral odontogenic fibroma, hemangioma caverosum and papilloma. ${ }^{28}$ Microscopic examination is required for definitive diagnosis.18Generally, this lesion is clinically indistinguishable from a pyogenic granuloma, although a peripheral giant cell granuloma is more likely to cause bone resorption than pyogenic granuloma, the differences are otherwise minimal. ${ }^{12}$ Microscopically, the lesion arises from, or is at least attached to the periodontal ligament or mucoperiosteum. ${ }^{34}$ The most characteristic histologic features included a non-encapsulated highly cellular mass with abundant giant cells, inflammation, interstitial hemorrhage, hemosiderin deposits, mature bone or osteoid. ${ }^{3}$ Fibroblasts are the basic element of peripheral giant cell granulomas. Scattered among the plump, young fibroblasts are numerous multinucleated giant cells with abundant eosinophilic cytoplasm which appear to be non-functional in the usual sense of phagocytosis and bone resorption. ${ }^{12}$ Two types of giant cells are mainly found, one representing metabolically active cells and the other representing dying cells. The origin of these cells has not been defined yet. However, a striking similarity between these cells and osteoclasts does exist. ${ }^{3}$ The prevalent of the two consists of multiple large, ovoid, vesicular, somewhat translucent nuclei with prominent nucleoli and the nuclear chromatin was located peripherally on distinct nuclear membrane. These cells are termed type I and vary in size, often 
exceeding $100 \mu$ in diameter. The type II giant cells are fewer in number, have smaller and more irregular nuclei than type I giant cells. The nucleoli are not easily seen and the cytoplasm stains deeply eosinophilic and granular than the cells of type I. ${ }^{5}$ Despite ultrastructural studies, the true nature of the giant cells in PGCG remains debatable. ${ }^{34}$

Inflammation is a constant finding but is varied not only in degree but also in location. The inflammatory cells consist primarily of lymphocytes, plasma cells, histiocytes and occasional polymorphonuclear cells. Rarely, ulceration was an associated feature. ${ }^{5}$ Vascular proliferation, especially capillary, was found in a study carried out by Peralles et al. ${ }^{29}$ Calcified tissue which is found in some of the lesions varies from small amorphous foci to well developed trabeculae. ${ }^{5}$ The woven bone or lamellar bone is thought to be produced by mononuclear stromal cells, which resemble latent proliferative osteoblasts orosteoprogenitor cells. ${ }^{13,14}$ Thus, it is not surprising that woven bone and lamellar bone are formed in PGCG. ${ }^{14}$ No correlation has been found between the presence or amount of bone with location or reported duration of the lesion. ${ }^{6,12,31}$ In rare instances, both a soft tissue and intraosseous lesion can co-exist. ${ }^{35}$ The overlying mucosal surface is ulcerated in about $50 \%$ cases. A "clear zone" of dense fibrous connective tissue usually separates the giant cell proliferation from the mucosal surface. ${ }^{1,5}$ The histopathologic picture of our case conformed to the above mentioned features with the periphery of the lesion exhibiting metaplastic woven bone formation. However, the brown tumors of hyperparathyroidism are much more likely to be intraosseous in location and mimic a central giant cell granuloma. 1 The blood chemistry examination in the present case was negative for hyperparathyroidism. Treatment consists of local surgical excision down to the underlying bone, ${ }^{1}$ for extensive clearing of the base. ${ }^{10}$ Removal of local factors or irritants is also required. ${ }^{12}$ If resection is only superficial, the growth may recur. 4 Exposure of all bony walls following thorough surgical resection responds satisfactorily most of the time. ${ }^{15}$ Recurrence rate of 5.0-70.6\% (average 9.9\%) has been reported in various epidemiologic studies (Mighell et al). ${ }^{24}$ A recurrence rate of 5\% has been reported by Giansanti and Waldron ${ }^{6}$ while a study by Eversole \& Rovinshowed a recurrence of $11 \% .{ }^{13}$ Recurrences are believed to be related to lack of inclusion of the periosteum or periodontal ligament in the excised specimen. ${ }^{12} \mathrm{~A}$ re-excision must be performed for these cases. ${ }^{1}$ Aggressive tendencies or malignant transformation of these lesions has never been reported. 3 PGCG lesions are self-limiting. ${ }^{5}$ The treatment rendered in our present case was oral prophylaxis followed by surgical excision and curettage.

The 1 year follow-up has shown no recurrence indicating that the given treatment along with maintenance of a good oral hygiene is sufficient to treat PGCG.

\section{Conclusion}

The usual line of treatment for PGCG is local excision down to the bony base along with elimination of the local etiologic factors. Failing to do so, results in the recurrence of the growth.

\section{Source of funding}

None.

\section{Conflict of interest}

None.

\section{References}

1. Neville BW, Damm DD, Allen CM, Bouquot JE. Soft Tissue Tumors. In Neville BW, Damm DD, Allen CM, Bouquot JE, eds. Oral and Maxillofacial Pathology 3rd ed. St. Louis: Saunders; 2009: 507-63.

2. Pour MAH, Rad M, Mojtahedi A. A Survey of Soft tissue Tumor-Like Lesions of Oral Cavity: A Clinicopathological Study. Iran J Pathol 2008;3:81-7.

3. Katsikeris N, Kakarantza-Angelopoulou E, Angelopoulos AP. Peripheral giant cell granuloma. Clinicopathologic study of 224 new cases and review of 956 reported cases. Int J Oral Maxillofac Surg 1988;17:94-9.

4. Flaitz CM. Peripheral Giant Cell Granuloma: A potentially aggressive lesion in children. Pediatr Dent 2000;22:232.

5. Bhaskar SN, Cutright DE, Beasley JD, Perez B. Giant cell reparative granuloma (peripheral): report of 50 cases. J Oral Surg 1971;29:110-15.

6. Giansanti JS, Waldron CA. Peripheral giant cell granuloma: review of 720 cases. J Oral Surg 1969;27:787-91.

7. Rajendran R. Benign and Malignant Tumors of the Oral Cavity. In Rajendran R, Sivapathsundaram B, eds. Shafer's Textbook of Oral Pathology 5th ed. New Delhi: Elsevier;2006: 113-308.

8. Gandara-Rey JM, Pacheo Martina Carneriro JL, Gandara- Vila $P$ et al. Peripheral giant-cell granuloma: Review of 13 cases. Med Oral 2002; 7:254-9.

9. Gunhan M, Gunhan O, Celasun B, Mutlu M, Bostanci H. Estrogen and progesterone receptors in the peripheral giant60. Kfir Y, Buchner A, Hansen LS. Reactive lesions of the gingiva. Aclinicopathological study of 741 cases. $J$ Periodontol 1980;51:655-61.

10. Hirshberg A, Kozlovsky A, Schwartz-Arad D, Mardinger O, Kaplan I. Peripheral giant cell granuloma associated with dental implants. J Periodontol 2003;74:1381-4.

11. Regezi JA, Sciubba JJ, Jordan RCK. Red-Blue lesions. In Regezi JA, Sciubba JJ, Jordan RCK, eds. Oral Pathology. Clinical Pathologic Correlations 5th ed. St. Louis: Saunders;2009: 107-25.

12. Eversole LR, Rovin S. Reactive lesions of gingiva. J Oral Pathol 1972;1:30-38.

13. Dayan D, Buchner A, Spirer S. Bone formation in Peripheral giant cell granuloma. J Periodontol 1990;61:444-6.

14. Motamedi MHK, Eshghyar N, Jafari SM et al. Peripheral and central giant cell granulomas of the jaws: A demographic study. Oral Surg Oral Med Oral Pathol Oral Radiol Endod 2007;103:e39-e43.

15. Kruse-Lösler B, Diallo R, Gaertner C, Mischke K-L, Joos U, Kleinheinz J. Central giant cell granuloma of the jaws: A clinical, radiologic and histopathologic study of 26 cases. Oral Surg Oral Med Oral Pathol Oral Radiol Endod 2006;101:34654.

16. Jaffe HL. Giant cell reparative granuloma, traumatic bonecyst and fibrous (fibro-osseous) dysplasia of jaw bones. Oral Surg 1953;6:159-75.

17. Carranza FA, Hogan EL. Gingival Enlargements. In Newman MG, Takei HH, Klokkevold PR, eds. Carranza's Clinical Periodontology 10th ed. St Louis: Saunders; 2009: 373-390. 
18. Carvalho YR, Lyola AM, Gomez RS, Ariyo VC. Peipheral giant cell granuloma.An immunohistochemical and ultrastructural study. Oral Dis 1995;1:20-5.

19. Regezi JA, Zarbo RJ, Lyoyd RV. Muramidase, alpha 1antitrypsin, alpha 1-antichemotrypsin and S-100 protein immunoreactivity in giant cell lesions. Cancer 1987;59:64-8.

20. Dayan D, Buchner A, David D. Myofibroblasts in peripheral giant cell granuloma. Light and electron microscopic study. Int J Oral Maxillofac Surg 1989;18:258-61.

21. Soames JV, Southam JC. Hyperplastic, neoplastic, and related disorders of oral mucosa. In Soames JV, Southam JC, eds. Oral Pathology 4th ed. New Delhi: Oxford University Press; 2005:101-115.

22. Parbatani R, Tinsley GF, Danford MH. Primary hyperparathyroidism presenting as a giant-cell epulis. Oral Surg Oral Med Oral Pathol Oral Radiol Endod 1998;85:2824.

23. Reichart PA, Philipsen HP. Gingiva. In Reichart PA, Philipsen HP, eds. Color Atlas of Dental Medicine. Oral Pathol. New York: Thieme; 2000: 148-75.

24. Bodner L, Peist M, Gatot A, Fliss DM. Growth potential of peripheral giant granuloma. Oral Surg Oral Med Oral Pathol Oral Radiol Endod 1997;83:548-51.

25. Zarei MR, Chamani G, Amanpoor S. Reactive hyperplasia of the oral cavity in Kerman province, Iran: A review of 172 cases. Br J Oral Maxillofac Surg 2007;45:288-92.

26. Salum FG, Yurgel LS, Cherubini K, De Figueiredo MA, Medeiros IC, Nicola FS. Pyogenic granuloma, peripheral giant cell granuloma and peripheral ossifying fibroma: retrospective analysis of 138 cases. Minerva Stomatol. 2008;57:227-32.

27. Chaparro-Avendano AV, Berini-Aytes L, Gay Escoda C. Peripheral giant cell granuloma. A report of five cases and review of literature. Med Oral Patol Oral Cir Bucal 2005; 10:48-57.
28. Peralles PG, Viana APB, Azevedo ALR, Pires FR. Gingival and alveolar hyperplastic reactive lesions: clinicopathological study of 90 cases. Braz J Oral Sci 2006;5:1085-89.

29. Esmeili T, Lozada-Nur F, Epstein J. Common benign oral soft Peralles PG, Viana APB, Azevedo ALR, Pires FR. Gingival and alveolar hyperplastic reactive lesions: clinicopathological study of 90 cases. Braz J Oral Sci 2006;5:1085-89.

30. Esmeili T, Lozada-Nur F, Epstein J. Common benign oral soft tissue masses. Dent Clin N Am 2005;49:223-40.

31. Cawson RA, Odell EW. Common benign mucosal swellings. In Cawson RA, Odell EW, eds. Cawson's Essentials of Oral Pathology \& Oral Medicine 7th ed. Spain: Churchill Livingstone; 2002:275-80.

32. Lucas RB. Giant cell lesions. In Lucas RB eds. Pathology of Tumors of the Oral Tissues. 4th ed. London: Churchill Livingston; 1984: 259-73.

33. Whitaker SB, Waldron CA. Central giant cell lesions of the jaws: a clinical, radiologic and histopathologic study. Oral Surg Oral Pathol Oral Med 1993;75:199-208.

34. Bonetti F, Pelosi G, Martignoni G. Peripheral giant cell granuloma: Evidence for osteoclastic differentiation. Oral Surg Oral Med Oral Pathol 1990;70:471-5.

35. Choi C, Terzian E, Schneider R, Trochesset DA. Peripheral giant cell granuloma associated with hyperparathyroidism secondary to end-stage renal disease: a case report. J Oral Maxillofac Surg 2008;66:1063-6.

How to cite this article: Chanchala HP, Tejasvi MLA. Peripheral gaint cell granuloma in a 9 year old girl. Int $J$ Oral Health Dent 2019;5(4):228-32. 